\title{
Article \\ From Climate Conditions to the Numerical Slope Stability Analysis of Surface Coal Mines
}

\author{
Alexandros I. Theocharis ${ }^{1}\left(\right.$, , Ioannis E. Zevgolis ${ }^{2, *} \mathbb{C}$, Alexandros V. Deliveris ${ }^{1}$, Rania Karametou ${ }^{1}$ \\ and Nikolaos C. Koukouzas ${ }^{1}$ \\ 1 Chemical Process \& Energy Resources Institute, Centre for Research \& Technology Hellas, \\ 15125 Athens, Greece; theocharis@certh.gr (A.I.T.); deliveris@certh.gr (A.V.D.); karametou@certh.gr (R.K.); \\ koukouzas@certh.gr (N.C.K.) \\ 2 School of Mining and Metallurgical Engineering, National Technical University of Athens, \\ 15773 Athens, Greece \\ * Correspondence: izevgolis@metal.ntua.gr
}

Citation: Theocharis, A.I.; Zevgolis, I.E.; Deliveris, A.V.; Karametou, R.; Koukouzas, N.C. From Climate Conditions to the Numerical Slope Stability Analysis of Surface Coal Mines. Appl. Sci. 2022, 12, 1538 https://doi.org/10.3390/ app12031538

Academic Editor: Cheng-Yu Ku

Received: 14 January 2022

Accepted: 29 January 2022

Published: 31 January 2022

Publisher's Note: MDPI stays neutral with regard to jurisdictional claims in published maps and institutional affiliations.

Copyright: (C) 2022 by the authors. Licensee MDPI, Basel, Switzerland. This article is an open access article distributed under the terms and conditions of the Creative Commons Attribution (CC BY) license (https:// creativecommons.org/licenses/by/ $4.0 /)$.
Featured Application: This work has application in coal and lignite mining excavations and areas, especially during decarbonization and towards a post-coal and post-lignite era. Areas that hosted coal and lignite mines are now being reclaimed - often by installing renewable energy systemsand targets are being set to fulfill new energy principles in relation to energy production, harvesting, and storage. The appropriate and sustainable exploitation of these areas is directly related to their safety and stability.

\begin{abstract}
A new perspective is presented for evaluating the slope stability of coal and lignite mines due to rainfall. The case of Greek lignite mining areas is employed to illustrate the methodology. Initially, past climatic records of rainfall are documented and analyzed; rainfall intensity varies from light $(0.8 \mathrm{~mm} / \mathrm{h}$ ) to heavy (up to $9 \mathrm{~mm} / \mathrm{h}$ ). Few extreme phenomena are documented, with the maximum intensity being $17 \mathrm{~mm} / \mathrm{h}$. Furthermore, climatic projections of future trends are performed with open-access tools to anticipate possible deviations from the baseline conditions. Although the mean temperature is expected to increase, projections show that the past rainfall range is not expected to change. Finally, the effect of rainfall infiltration on the stability of a typical open-pit lignite mining slope is investigated by finite element analysis. The precipitation range defined by the environmental analysis is used. The SF is practically constant for the lower rainfall intensities $(0.8-2.2 \mathrm{~mm} / \mathrm{h})$. For the higher intensities of $6.4 \mathrm{~mm} / \mathrm{h}, 9 \mathrm{~mm} / \mathrm{h}$, and $17 \mathrm{~mm} / \mathrm{h}$, the SF decrease is almost the same (from 2.08 to 1.9 ), with reduction rates of $8.3 \%, 8.9 \%$, and $9.3 \%$, respectively. The effect of the critical geotechnical properties-groundwater table depth, unsaturated zone properties, and soil permeability-is also examined for a complete evaluation.
\end{abstract}

Keywords: environmental engineering; geotechnical engineering; mining and environmental issues; mine reclamation; climate change; lignite

\section{Introduction}

Coal and lignite have contributed to global energy needs for several decades, accounting for 30\% of the global energy production in 2010 and 27\% in 2020 [1]. The transition to cleaner energy has led to mine closures in Europe and globally. With the shift in the energy mix and the groundbreaking changes in the economy's structure, coal regions should not be left behind, and the economic and social impact of mine closures should not be ignored. Decarbonization will leave vast areas of closed mines and waste dumps that burden community unless suitably reclaimed. For the reclamation of these areas, their safety and stability are crucial, as they are jeopardized by several factors. Rainfall is typically such a crucial factor, particularly given the effect of climate change on its evolution. 
Intense rainfall and extreme weather events are often associated with landslides and catastrophes on natural or engineered slopes. The analysis and design of such slopes are currently largely based on numerical modeling. Several numerical methods have been developed for slope stability analysis, with two dominating the field: the limit equilibrium method (LEM) and the finite element method (FEM). These stability methods are typically coupled with a finite element analysis considering groundwater evolution during rainfall infiltration. As a result, many works, e.g., [2-5], use the FEM for groundwater, rainfall, and stability, while others, e.g., [6-9], combine the FEM and the LEM.

The influence of rainfall on the slope stability of open-pit coal and lignite mines has long been identified and considered for design purposes, e.g., [10-12]. The investigation of precipitation's impact on mining slope stability has been primarily based on observations and empirical correlations between precipitation rates and increasing slope movements, e.g., [13]. This type of slope analysis, although practical, has only incorporated rain in indirect ways, e.g., the rise of the groundwater table rise or the increase of pore water pressures.

In contrast, slope stability analysis of cut slopes (civil infrastructure) has progressed tremendously, employing unsaturated soil mechanics and advanced hydrological concepts to incorporate precipitation into numerical modeling, e.g., [2,5,14-16]. However, even in these cases, precipitation has been considered through parametric analyses, with precipitation characteristics usually dictated by general considerations.

Differences among the two types of slopes (cut slopes in civil infrastructure versus overburden soil slopes in coal mines) refer mainly to: the enormous height of the mines' excavations, up to $200 \mathrm{~m}$, versus heights up to $30-40 \mathrm{~m}$ for cut slopes; the smooth inclination usually utilized for excavations (versus steeper slopes often encountered in infrastructure); the large tolerance in displacements in mining slopes (even in the order of magnitude of meters) versus more strict limitations for typical cut slopes. Additionally, the soil types of cut slopes are frequently different from the excavation materials, including lignite deposits and seams and spoil materials, presenting considerable variability.

A novel methodology is presented to evaluate coal and lignite mine slope stability due to precipitation. The stability of these areas is essential, especially during the current period of decarbonization and movement towards the post-coal and post-lignite era. Areas that hosted coal and lignite mines are now being reclaimed, e.g., by installing renewable energy systems, and new energy principles relating to energy production, harvesting, and storage are being set. The appropriate exploitation of these areas is directly related to their safety and stability in sustainably contributing to the new era.

The proposed framework is formulated to be used in various conditions. An indepth climatic analysis appropriately defines the parameters and specifies the range of rainfall intensity for stability purposes. Initially, the baseline rainfall is established from reported climatic conditions for the last thirty years and extreme events of the last ten years. Furthermore, climatic projections are used to anticipate trends and possible changes in the baseline, past, and current rainfall conditions. Finally, a typical slope representing a mine excavation is simulated within the anticipated climatic conditions. The finite element method (FEM) is employed, and a fully coupled flow-deformation analysis is conducted that allows for the simultaneous evaluation of the unsaturated transient seepage flow and the mechanical response of the soil. A parametric analysis is conducted for the critical geotechnical parameters. Greek lignite areas are used as a case example; however, the methodology and insights apply to several similar surface slopes. The numerical model (geometry, properties) can be implemented similarly in many countries where similar conditions are found. The results of this work can be used as a guideline for similar situations.

\section{The Methodology and the Case Example of Greek Lignite Mines}

The present study presents a methodological framework including the assessment of past and current rainfall, future rainfall projections, and numerical analysis of the effect of 
rainfall on the slope stability of a case example. Figure 1 presents an overview of this work's methodology. This flowchart focuses on the slope stability of surface coal mines at the center and includes all aspects as conceptualized herein. Table 1 summarizes the main parameters of each aspect for some previous characteristic studies, analyzed in the following: $\mathrm{g}_{\mathrm{a}}$ is a parameter of the soil-water characteristic curve; $\varphi^{\prime}$ and $c^{\prime}$ are the effective friction angle and cohesion; $\mathrm{k}_{\mathrm{s}}$ is the saturated permeability; $\mathrm{H}$ is the height of the slope; $\mathrm{q}$ is rainfall intensity; $\mathrm{H}_{\mathrm{w}}$ defines the groundwater table's depth. The upper part of Figure 1 describes the present work's approach to evaluating precipitation, while for the other aspects, the most critical parameters are included in a parametric analysis. Unlike previous works where precipitation was estimated based on global data $[2,3,5,9,16-25]$ or was derived for a specific period as a particular time series [3,14,26-30], the way to assess the precipitation range is through past events and climate projections of the investigated area. This approach provides a clear advantage in terms of how the rainfall range is calculated. Greek mining areas are utilized to quantify the precipitation range because it is area-specific, and the methodology followed needs specific to the areas to be implemented.

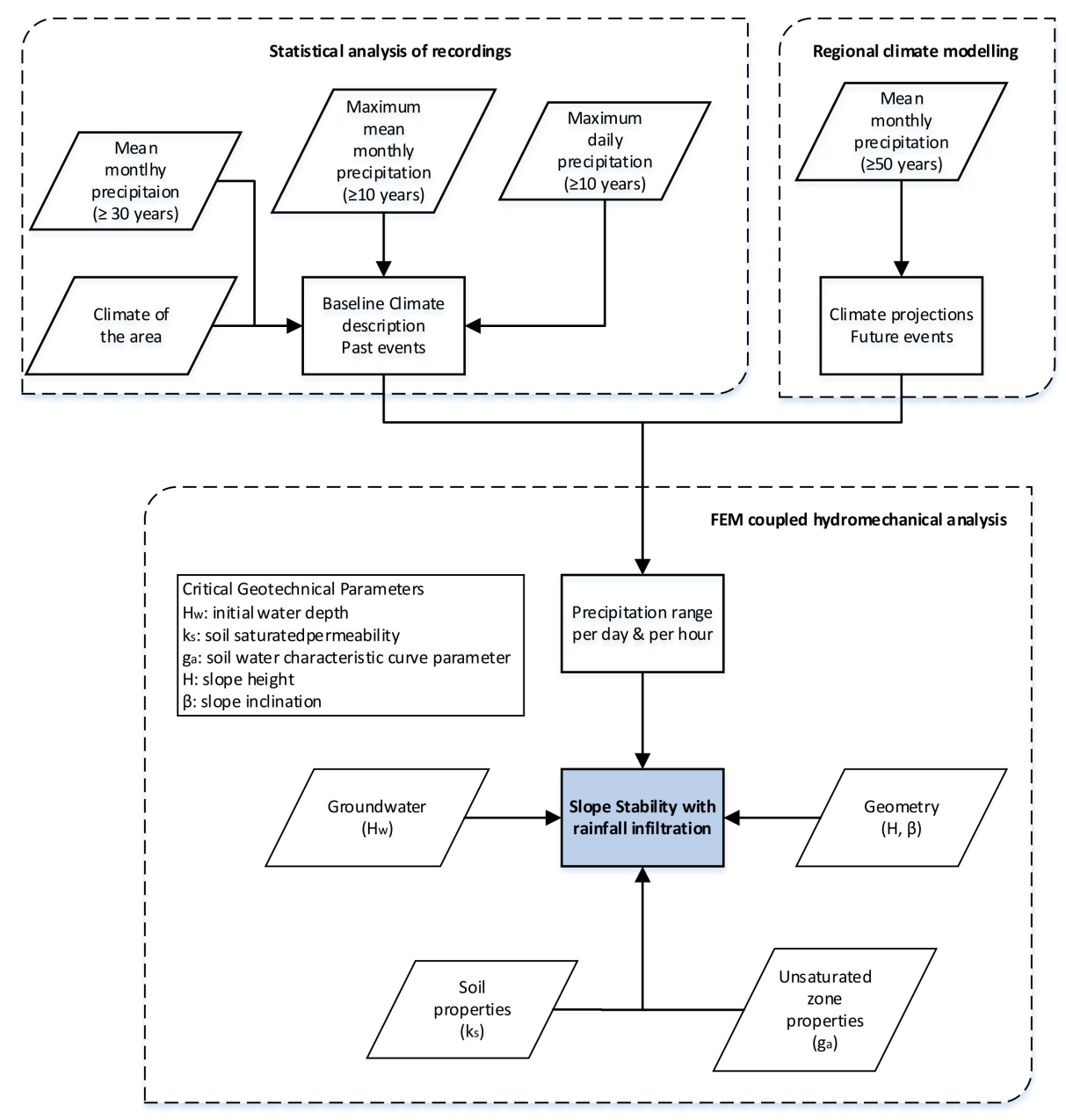

Figure 1. Flowchart presenting an overview of this work's methodology. 
Table 1. Basic parameters of previous characteristic studies.

\begin{tabular}{|c|c|c|c|c|c|c|c|c|}
\hline References & $\underset{\left(m^{-1}\right)}{g_{a}}$ & $\begin{array}{l}\varphi^{\prime} \\
\left(^{\circ}\right)\end{array}$ & $\begin{array}{c}c^{\prime} \\
(\mathbf{k P a})\end{array}$ & $\mathrm{k}_{\mathrm{s}}(\mathrm{cm} / \mathrm{s})$ & $\mathrm{H}(\mathrm{m})$ & $\begin{array}{c}\mathrm{q} \\
(\mathrm{mm} / \mathrm{h})\end{array}$ & $\begin{array}{l}\mathbf{H}_{\mathrm{w}} \\
(\mathrm{m})\end{array}$ & Comments \\
\hline $\begin{array}{l}\text { Cai and } \\
\text { Ugai [2] }\end{array}$ & $1.06-7.09$ & 25 & 8 & $10^{-4}-6 \times 10^{-3}$ & 10 & $5-50$ & $* 0$ & Cut \\
\hline $\begin{array}{l}\text { Zhang, } \\
\text { Fredlund, } \\
\text { Zhang, and } \\
\text { Tang [20] }\end{array}$ & $0.05-10$ & - & - & $10^{-3}$ & 20 & $0.036-18$ & $* * 20$ & Cut \\
\hline $\begin{array}{l}\text { Griffiths and } \\
\text { Lu [6] }\end{array}$ & $0.05-0.5$ & $20-30$ & $5-10$ & $10^{-11}-10^{-3}$ & 10 & $4 \times 10^{-8}-10^{-3}$ & * 2.5 & Cut \\
\hline $\begin{array}{c}\text { Rahardjo, Ong, } \\
\text { Rezaur, and } \\
\text { Leong [5] }\end{array}$ & $0.1-10$ & 26 & 10 & $10^{-4}-10^{-2}$ & $5-40$ & 9-900 & * $2.5-15$ & Natural \\
\hline $\begin{array}{c}\text { Rahimi, } \\
\text { Rahardjo, and } \\
\text { Leong [9] }\end{array}$ & $0.01-10.0$ & 26 & 10 & $10^{-5}-10^{-2}$ & 15 & $0.036-360$ & $* 2$ & Natural \\
\hline $\begin{array}{l}\text { Tommasi, } \\
\text { Boldini, } \\
\text { Caldarini, and } \\
\text { Coli [27] }\end{array}$ & 0.02 & 21 & 18 & $1 \times 10^{-4}$ & 100 & $0.02-4.2$ & - & $\begin{array}{c}\text { Natural-Case } \\
\text { study }\end{array}$ \\
\hline $\begin{array}{c}\text { Leshchinsky, } \\
\text { Vahedifard, } \\
\text { Koo, and Kim } \\
\text { [28] }\end{array}$ & 0.20 & 20 & 15 & $5 \times 10^{-3}$ & 58 & $0.04-10.4$ & - & $\begin{array}{l}\text { Natural-Case } \\
\text { study }\end{array}$ \\
\hline $\begin{array}{c}\text { Qi and } \\
\text { Vanapalli [24] }\end{array}$ & $0.03-1.00$ & 17.5 & 5 & $4 \times 10^{-9}-6 \times 10^{-7}$ & 20 & 0.02 & * 8-23 & Cut \\
\hline $\begin{array}{l}\text { Robinson, } \\
\text { Vahedifard, } \\
\text { and AghaK- } \\
\text { ouchak [4] }\end{array}$ & 1.60 & 30 & 10 & $4 \times 10^{-4}$ & 10 & $2.1-4.2$ & $* 2$ & Cut \\
\hline $\begin{array}{l}\text { Yeh and } \\
\text { Tsai [25] }\end{array}$ & $0.1-1.0$ & 26 & 10 & $10^{-4}-10^{-2}$ & 10 & $0.8-30$ & * 10 & Cut \\
\hline $\begin{array}{c}\text { Rouainia, } \\
\text { Helm, Davies, } \\
\text { and Glendin- } \\
\text { ning [16] }\end{array}$ & 0.08 & 20 & 7 & $10^{-7}$ & 8 & $21-43$ & $* 1$ & Cut \\
\hline $\begin{array}{l}\text { Chen, Zhang, } \\
\text { Zhang, Zhou, } \\
\text { Ye, and Guo [3] }\end{array}$ & 1.00 & 26 & 30 & $510^{-3}$ & 125 & $0.1-2.5$ & $* * 0$ & $\begin{array}{l}\text { Natural-Case } \\
\text { study }\end{array}$ \\
\hline Current Study & $0.001-0.1$ & 25 & 50 & $10^{-5}-10^{-3}$ & 50 & $0.8-17.0$ & $* * 10-40$ & Cut \\
\hline
\end{tabular}

The lower part of the flowchart describes the slope (geometry, groundwater, soil, and unsaturated zone properties). As briefly mentioned in the introduction, the geometry of surface coal and lignite mines differs from embankments, cut, or natural slopes. Previous studies have mainly focused on engineered slopes less than $30 \mathrm{~m}$ high, with one work studying a slope reaching $40 \mathrm{~m}$ [5]. Additionally, three works have analyzed natural slopes of more than $50 \mathrm{~m}$, but these present case studies and not systematic analyses of this type of slope $[3,27,28]$, thus ignoring methodological issues and not evaluating the effect of the various parameters. Moreover, the groundwater conditions, crucial for the stability, differ in surface mine slopes; in the literature, a narrow range is commonly employed 
for the depth of the groundwater table, usually evaluated as horizontal or with a small inclination. In surface mines, the water reaches the toe of the slope, and inside the slope, the steady-state flow of the water varies significantly due to varying initial conditions and drainage wells. These are considered in the analysis that follows through a steady-state groundwater flow with largely varying groundwater depth.

Finally, soil properties, including the unsaturated zone, are case- and site-specific. Due to the lignite basins' creation process, it is common to observe fine-grained materials overlying and mixing with the lignite layers and seams. In this work, Greek lignite mines are employed for the soil properties that represent fine-grained materials. Theocharis et al. [31] recently discussed an overview of the geotechnical characterization of the soil materials found in Greek lignite mines. Nevertheless, these properties are not specific to a site but characterize this type of surface mine slope.

Greek mines have been systematically exploited and were made extremely large and deep to increase lignite excavation production and efficiency. Exploitable lignite deposits are principally located in Western Macedonia (northern Greece) and secondarily in the Peloponnese (southern Greece) (Figure 2). In the first case, the central basin is PtolemaisAmyntaio, while in the Peloponnese, the lignite basin is at the Megalopoli area. Greek lignite mines present a ground profile with an overburden zone of sterile materials (soilrock deposits of several tens of meters) and a lower zone of exploitable lignite deposits. The sterile material primarily consists of marls and stiff or even hard clays, while weaker cohesive soils and sands are also observed, e.g., [32,33]. As a result, soil mechanics (rather than rock mechanics) principles are central to stability issues.

Overall, several researchers have analyzed the geologic formations, e.g., [33], and ground profiles of Greek lignite mines from a geotechnical perspective, e.g., [32,34]. Due to the immense excavations, large and deep slopes are created during open-pit mining. Thus, slope stability is critical for safe and efficient lignite mining and the valorization of lignite mining areas after closure and abandonment. Moreover, the geotechnical characterization of the soils found on the slopes is vital for slope stability analysis. Several past failures demonstrate that slope stability has not always been rigorously evaluated, resulting in problems in the mines' safety and management [34], often related to rainfall events.

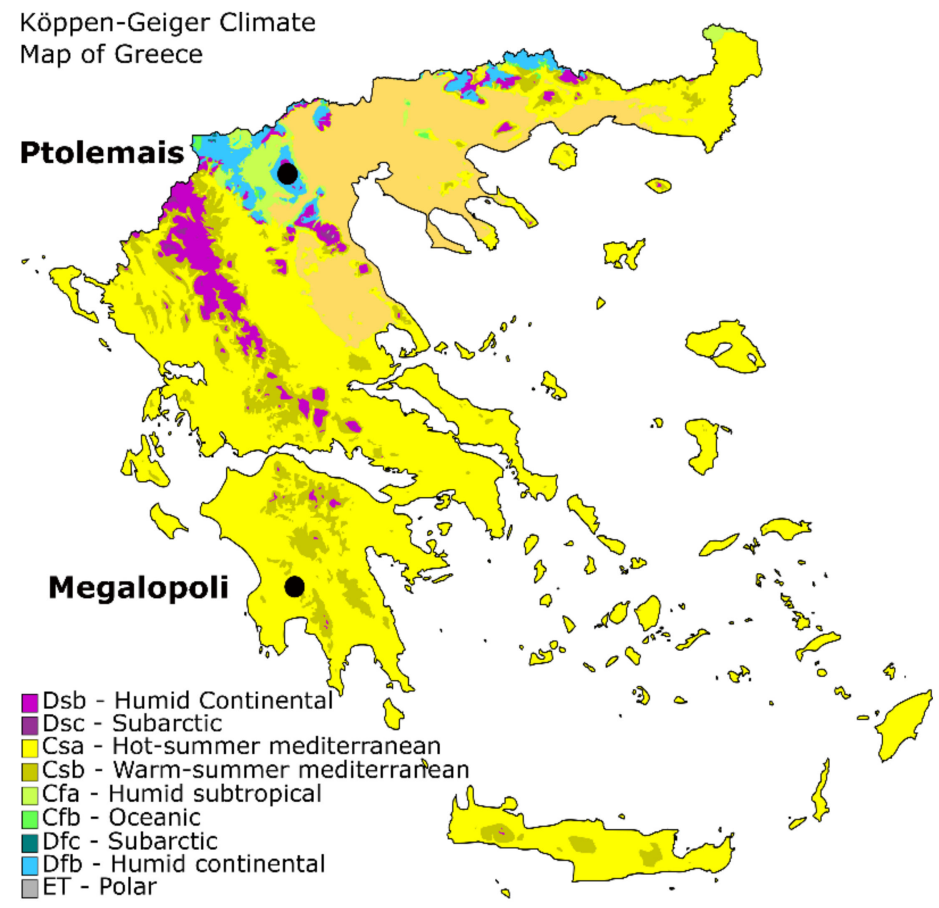

Figure 2. Geographical distribution of lignite mining areas and Koppen-Geiger classification for Greece [35]. 


\section{Baseline Climate Description-Past Events}

Greece is located in the southern part of the Balkan peninsula, in southeastern Europe. It mainly presents a typical Mediterranean climate (Figure 2) with mild, rainy winters, warm, dry summers, and extended periods of sunlight [36]. The area of Megalopoli is representative of this climate; in contrast, the region of Western Macedonia presents a climate similar to continental Europe [37].

The climate of Megalopoli is categorized as Csa (hot summer Mediterranean) according to the Köppen-Geiger climate classification, having hot summers and mild winters [35] (Figure 2). Most rainfall days are recorded during fall and winter with an annual average precipitation of $800 \mathrm{~mm}$; the driest month is July, and the wettest is December, with an average monthly precipitation of $9 \mathrm{~mm}$ and $147 \mathrm{~mm}$, respectively [38]. The average temperature in Megalopoli is $14.9^{\circ} \mathrm{C}$.

The climate of Ptolemais is classified as $\mathrm{Cfb}$ (temperate oceanic) according to the Köppen-Geiger climate classification, having intense winters and mild summers with a very low number of dry days (Beck, 2018) (Figure 2). Rainfall in plain areas ranges from $600-800 \mathrm{~mm} /$ year [39]. There are 108.3 average rainfall days, with August being the driest month, with $30 \mathrm{~mm}$ of rain, and November the wettest, with $60.3 \mathrm{~mm}$ of average precipitation. The mean annual temperature is $11.5^{\circ} \mathrm{C}$.

The quantification of past and current climate conditions depends on the measurements obtained from several weather stations in an area. Figure 3 presents the precipitation for these two regions for the last 30 years (1990-2019) (data provided by the Hellenic National Meteorological Service). Both regions present fluctuations, but they are practically constant in these 30 years. Megalopoli's precipitation level is overall higher and presents more sharp fluctuations than the Ptolemais one. For example, the maximum mean monthly precipitation difference between two consecutive years was $33 \mathrm{~mm}$ for Ptolemais (2013-2014) and $51 \mathrm{~mm}$ for Megalopoli (2004-2005). For Ptolemais, the mean precipitation per month is $37 \mathrm{~mm}$, and for Megalopoli, $56 \mathrm{~mm}$. Assuming this precipitation falls in one day, the rainfall intensity is $1.5 \mathrm{~mm} / \mathrm{h}$ in Ptolemais and $2.3 \mathrm{~mm} / \mathrm{h}$ in Megalopoli, denoting light rain. By obtaining the maximum mean monthly precipitation of $64 \mathrm{~mm}$ in Ptolemais and $88 \mathrm{~mm}$ in Megalopoli and making the same assumption, one obtains $2.7 \mathrm{~mm} / \mathrm{h}$ and $3.7 \mathrm{~mm} / \mathrm{h}$, respectively, denoting a moderate rain intensity.

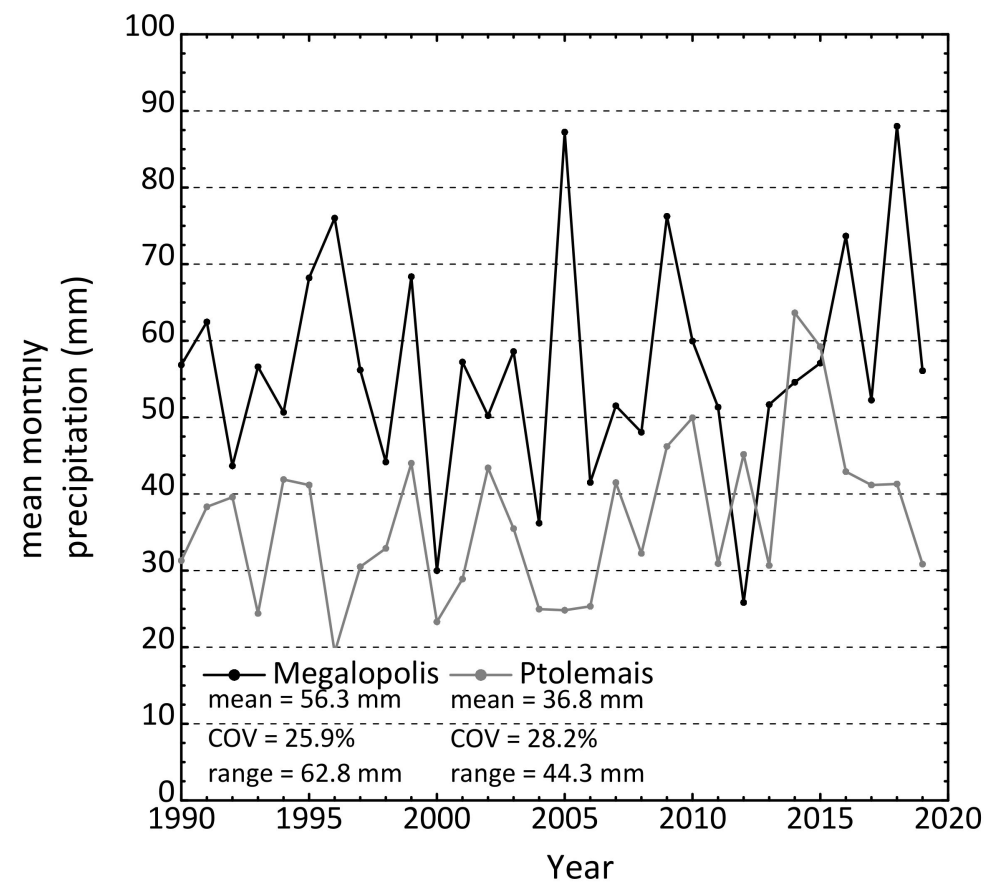

Figure 3. Measurements of the last 30 years of mean monthly precipitation from 1990-2019. 
More detailed data for the precipitation in these areas were obtained from the National Observatory of Athens up to ten years ago, for two meteorological stations different but close to previous ones (data publicly available). They do not cover the 30 years that is the classical period used for describing a climate (World Meteorological Organization) but are more detailed in terms of rainfall activity. Figure 4 presents the maximum mean monthly precipitation per year (the $x$-axis refers to the month with the highest mean precipitation) and the maximum daily precipitation per year (the $x$-axis refers to the day with the highest precipitation) for the past ten years. Figure 4a shows that the maximum mean monthly precipitation per month can be four times larger than the mean monthly one. For instance, in 2019, for Ptolemais, the mean monthly precipitation was $30.8 \mathrm{~mm}$ and the maximum $92.6 \mathrm{~mm}$, and for Megalopoli, $88 \mathrm{~mm}$ and $381 \mathrm{~mm}$, respectively. These observations denote that more extreme rains than assessed by the mean monthly values are possible; if these maximum mean monthly rains are assumed to fall in one day, that would dictate $4 \mathrm{~mm} / \mathrm{h}$ and $16 \mathrm{~mm} / \mathrm{h}$.

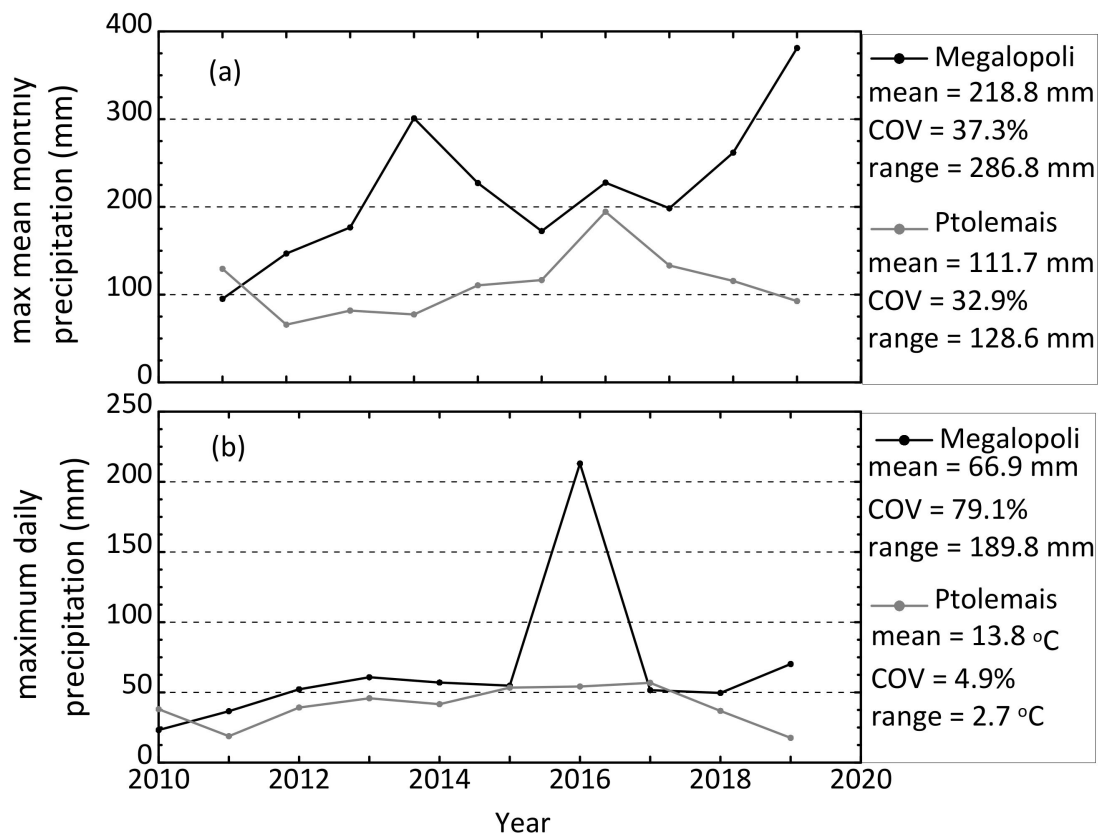

Figure 4. Measurements for the last ten years of (a) maximum mean monthly and (b) maximum daily precipitation.

Figure $4 \mathrm{~b}$ presents maximum daily rains similar to the mean monthly precipitation, supporting the assumption that the mean monthly precipitation can fall in one day. For example, in 2015, Ptolemais' mean monthly precipitation was $59.2 \mathrm{~mm}$, and the maximum daily precipitation was $53.4 \mathrm{~mm}$, while in Megalopoli, the corresponding values were $57.1 \mathrm{~mm}$ and $54.8 \mathrm{~mm}$, respectively. One exception denoted by an extreme rainfall event in Megalopoli in 2016 (when more than $200 \mathrm{~mm}$ of precipitation fell in one day) signifies that extreme events, where the maximum mean monthly rainfall falls at one time, are also possible. In that case, $213 \mathrm{~mm}$ of precipitation within one day corresponds to $8.9 \mathrm{~mm} / \mathrm{h}$, a heavy rain intensity. Due to its severe intensity, this event was also documented in the local press.

\section{Climate Projections-Future Events}

Climate change's impact on various systems and activities tends to increase incrementally with each day. Thus, it is necessary to anticipate its effects, especially concerning temperature and rainfall events affecting mining operations and reclamation, infrastructure maintenance, and management. Climate change directly influences temperature and precipitation in an increasing or decreasing manner, depending on the study area. Various 
aspects of climate change are analyzed in the literature due to its importance and broad implications, e.g., [40].

Specifically for the mining sector and the infrastructure, climate parameters should be projected in the future to prevent failures and catastrophic events. In this way, extreme future events can be considered for planning operations and designs. In this section, future rainfall and temperature are estimated for the Ptolemais area, with specific emission scenarios being the key ingredient of the analysis. The focus is on the climatic parameters' trends to evaluate if the past conditions will remain valid in the future.

The World Climate Research Programme (WCRP) is the framework utilized in this work for climate projections; it provides tools that monitor, simulate, and project global climate conditions with high accuracy, being a rigorous framework built through international science coordination and partnerships. WCPR established the Coordinated Regional Downscaling Experiment (CORDEX) to produce regional climate projections for all continents [41]. The Earth System Grid Federation, a global consortium of data providers and data archives with a shared infrastructure, is used to access the CORDEX data [42].

Climate evolution can be simulated by global climate models and regional climate downscaling techniques. A global climate model can produce reliable projections on how average conditions will change in an area larger than $1000 \mathrm{~km}$ by $1000 \mathrm{~km}$ over the coming decades [43]. It is based on fundamental laws of matter and energy and uses mathematical equations to describe the earth's elements (e.g., atmosphere, oceans, land surface, and ice). Nevertheless, global climate models are inadequate in regions with complex orography [44].

During the last decades, regional climate downscaling techniques have provided higher resolution climate information [45] by combining regional climate models, global climate models, and empirical statistical downscaling. Regional models typically have $10-50 \mathrm{~km}$ resolution and detail all the local climate characteristics. A global climate model is always needed to provide the boundary conditions at the regional model's edges. This work uses eight regional climate models (named datasets) to assess the Ptolemais mine area's future climate conditions. These datasets originate from different assumptions regarding fundamental laws and constants. Thus, assessing all eight provides a solid basis for evaluating future climatic trends.

The quantity of future greenhouse gas emissions is the critical element in predicting climate conditions and a source of great uncertainty. For this reason, four scenarios known as Representative Concentration Pathways (RCP) were developed by the Intergovernmental Panel on Climate Change of the United Nations and are systematically used in the literature. The RCPs describe different climate futures, all considered possible depending on the volume of greenhouse gases emitted in the years to come. The present work considers two emission scenarios: RCP 4.5, the median range or stabilization scenario, and RCP 8.5, the high-end, dystopian scenario. The output variables are presented as monthly averages, and of interest are the trends.

The mean monthly temperature projections (not presented herein) present an increase of about $1-2{ }^{\circ} \mathrm{C}$ for RCP 4.5 and up to $4{ }^{\circ} \mathrm{C}$ for RCP 8.5. These observations agree well with those of previous works and project an increase in temperature of $1-5{ }^{\circ} \mathrm{C}$ [46]. The different datasets provide a wildly different range in the initial (2020-2029) mean monthly precipitation (Figure 5), e.g., from $19 \mathrm{~mm}$ (Dataset 1) to $80 \mathrm{~mm}$ (Dataset 8) for RCP 4.5. This initial range is due to the different assumptions employed by the different models and does not affect the evolution's reliability. Focusing on the projections, the precipitation level remains practically the same for all datasets. No clear trend of increase or decrease is observed, and current conditions remain the same. As a result, it is presumed that the intensity of extreme events will not change drastically and will not result in violent rains (e.g., more than $16 \mathrm{~mm} / \mathrm{h}$ for more than $24 \mathrm{~h}$; see the previous section). Notice that this area's precipitation evolution differs from the general overview of the Mediterranean area that projects smaller mean precipitation and more extremes [46]. This disagreement is explained, as local conditions crucially affect the overall evolution and result in various trends. 

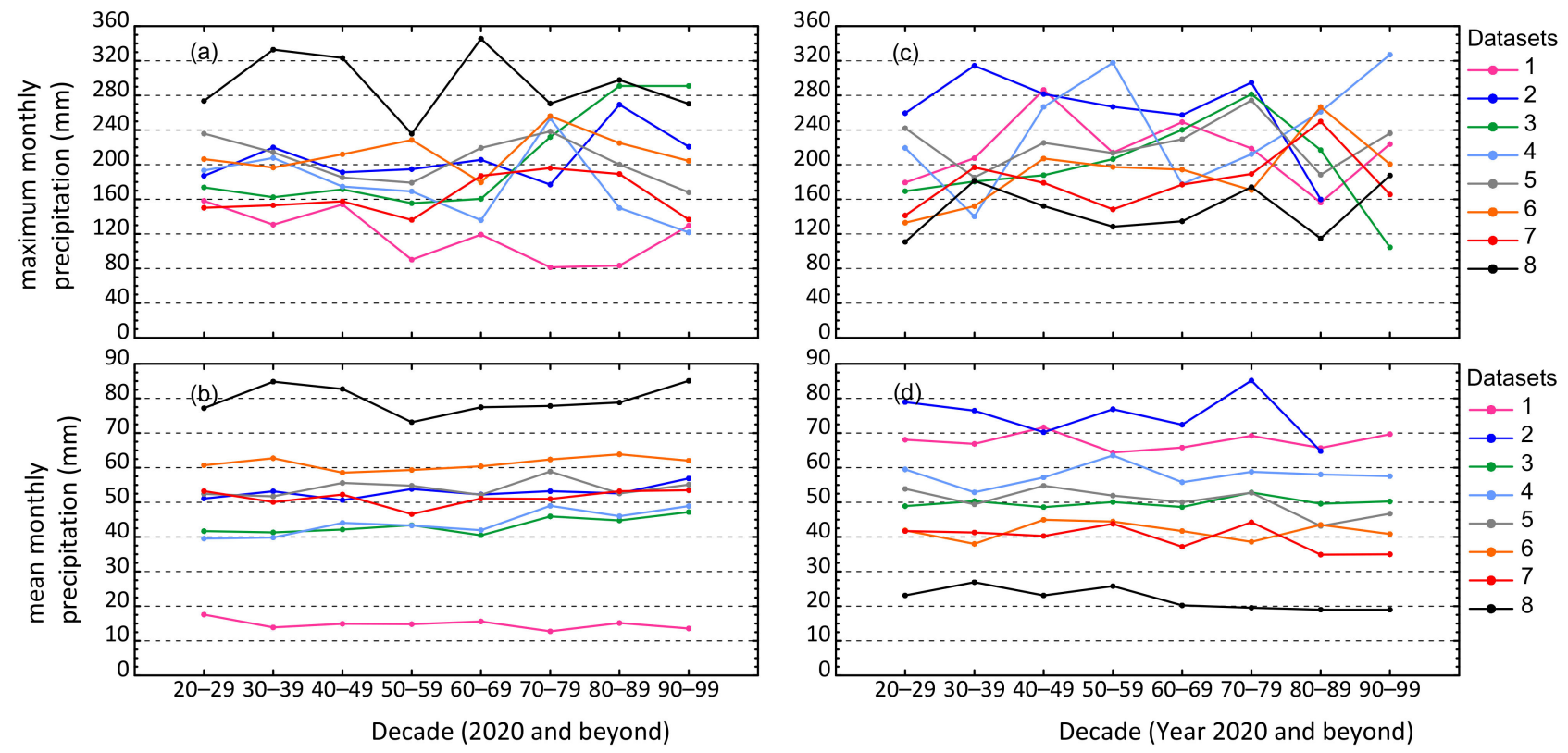

Figure 5. Mean and maximum monthly precipitation projections for the 2020-2099 period for the $(\mathbf{a}, \mathbf{b})$ RCP 4.5 and $(\mathbf{c}, \mathbf{d})$ the RCP 8.5 scenario.

Overall, Figure 3 proposes a mean monthly rainfall less than $90 \mathrm{~mm}$ for Megalopoli and $60 \mathrm{~mm}$ for Ptolemais; Figure 4a a maximum mean monthly rainfall up to about $400 \mathrm{~mm}$ for Megalopoli and $200 \mathrm{~mm}$ for Ptolemais; and Figure 5a a future mean monthly rainfall for Ptolemais that can be up to $350 \mathrm{~mm}$. As discussed in the previous paragraph, climate projections mainly reveal trends, not absolute values. As suggested in the previous section, these rainfalls can also represent maximum daily values and extreme events when the mean or maximum rainfall of a month falls in one day. Given this perspective, Megalopoli's precipitation range is approximately $20-400 \mathrm{~mm}$ and Ptolemais's $20-200 \mathrm{~mm}$ per day, including extreme weather events and incorporating future changes. These precipitation rates can be translated on an hourly basis for simulation purposes as $0.8-17 \mathrm{~mm} / \mathrm{h}$ for Megalopoli and $0.8-9 \mathrm{~mm} / \mathrm{h}$ for Ptolemais. These rates are accurate enough for an informed evaluation of precipitation and its effect on slope stability.

\section{Numerical Analysis of Slope Stability of Lignite Mines under Extreme Rainfall Events}

\subsection{Numerical Model Overview}

The finite element method (FEM) is employed to investigate how rainfall affects pit mining slope stability. A fully coupled flow-deformation analysis is conducted using a geotechnical finite element software that allows for the simultaneous evaluation of the unsaturated transient seepage flow and soil mechanical response [47]. For slope stability analysis, the FEM needs to be combined with the strength reduction technique to calculate the safety factor (SF); the soil material's strength is gradually reduced until failure [48].

The simulation of rain infiltration requires the consideration of the unsaturated zone that lies above the groundwater table. The soil-water characteristic curve (SWCC) is usually employed for this type of analysis. It indicates the unsaturated soil's capacity to retain moisture at various stress levels and typically relates water content to soil suction. Furthermore, a relationship is needed to express the unsaturated soil permeability at different moisture levels, i.e., the unsaturated soil's drainage capacity. Finally, during rainfall, the precipitation does not completely infiltrate the soil. A possibly substantial part of it flows as runoff water on the soil's surface. The unsaturated soil permeability governs the part of the rainfall that infiltrates, and a small excess of water is considered to stagnate. The rest of the water is runoff water that does not affect stability. 
Through the SWCC and the permeability function, the assessment of soil behavior in the unsaturated zone is feasible for most geotechnical engineering applications [49]. In this study, unsaturated soil behavior is captured by a form of the widely known van GenuchtenMualem model $[50,51]$. The soil saturation, $S_{w}$, in the unsaturated zone, is described as a function of the matric suction, $\mathrm{u}_{\mathrm{w}}$ (negative pore-water pressure), according to:

$$
S_{\mathrm{w}}=S_{\mathrm{r}}+\left(S_{\mathrm{s}}-S_{\mathrm{r}}\right) \cdot\left[1+\left(\mathrm{g}_{\mathrm{a}} \cdot \frac{\left|\mathrm{u}_{\mathrm{w}}\right|}{\gamma_{\mathrm{w}}}\right)^{\mathrm{g}_{\mathrm{n}}}\right]^{\frac{1-\mathrm{g}_{\mathrm{n}}}{\mathrm{g}_{\mathrm{n}}}}
$$

where $S_{r}$ denotes the soil's residual saturation; $S_{\mathrm{S}}$ the soil saturation at the saturated state; $\mathrm{g}_{\mathrm{a}}$ and $\mathrm{g}_{\mathrm{n}}$ are material parameters governing the shape of the SWCC; and $\gamma_{\mathrm{w}}$ is the water's unit weight $\left(9.81 \mathrm{kN} / \mathrm{m}^{3}\right)$.

The residual saturation degree $S_{\mathrm{r}}$ and the material parameter $\mathrm{g}_{\mathrm{a}}$ are critical factors for the unsaturated soil's state [52]. In this work, the residual degree of saturation, $S_{r}$, was assumed to equal 0.2, a typical value for fine-grained soils, and the reference $g_{a}$ to equal $0.01 \mathrm{~m}^{-1}$. However, the range of this parameter for fine-grained soil materials of $0.001-0.1 \mathrm{~m}^{-1}$ was considered through a parametric analysis $[16,27,30,53,54]$. This range slightly differs from the literature, referring more to surface mines with fine-grained soils; thus, it has not been thoroughly examined, especially concerning the precipitation range investigated herein. Finally, the parameter $\mathrm{g}_{\mathrm{n}}$ is assumed to equal 1.3, representing finegrained soils [55]. Figure 6 presents the SWCC for three different values of $g_{a}$. As $g_{a}$ decreases, the suction needed to initiate soil's desaturation (95\% of the saturation degree) increases. The soil parameter $\mathrm{g}_{\mathrm{n}}$ is constant, leading to the same gradient of the linear part of the three SWCCs. Finally, the residual saturation $S_{r}=0.2$ is constant, and all three curves will eventually reach that value for large suction.

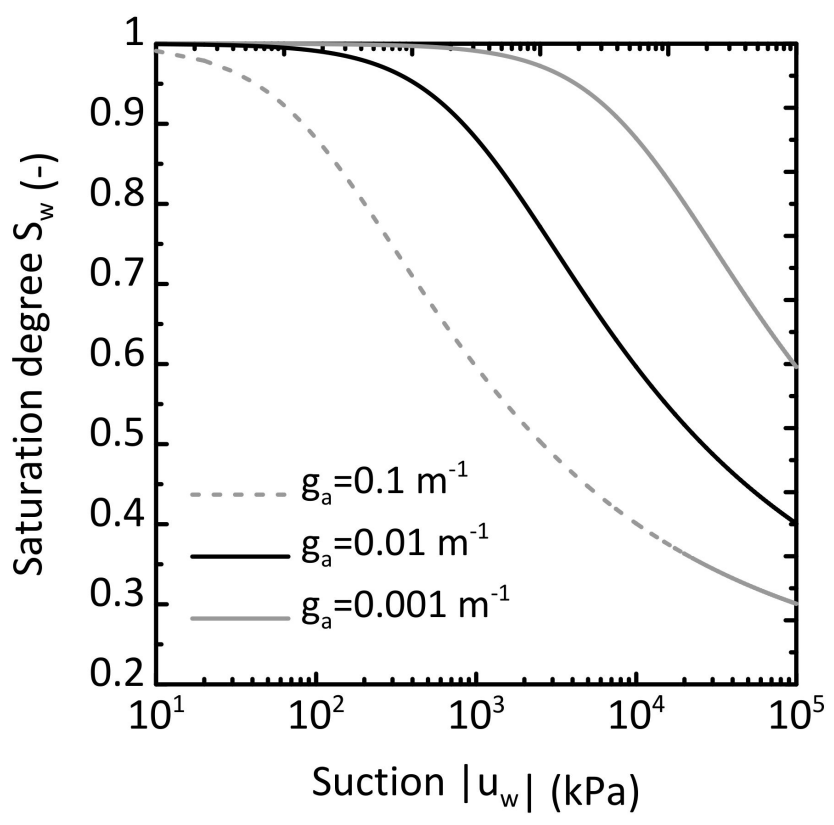

Figure 6. Soil-water characteristic curve for different material parameters, $\mathrm{g}_{\mathrm{a}}$

Furthermore, unsaturated hydraulic conductivity is also a matric suction function [56]. According to the van Genuchten-Mualem model:

$$
\mathrm{k}_{\mathrm{w}}=\mathrm{k}_{\mathrm{s}} \cdot \mathrm{S}_{\mathrm{e}}^{\mathrm{g}_{1}} \cdot\left[1-\left(1-\mathrm{S}^{\frac{\mathrm{g}_{\mathrm{n}}}{\mathrm{g}_{\mathrm{n}}-1}}\right)^{\frac{\mathrm{g}_{\mathrm{n}}-1}{\mathrm{~g}_{\mathrm{n}}}}\right]^{2}
$$


where $\mathrm{g}_{1}$ is a fitting parameter equal to 0.5 , regardless of the soil type. The effective degree of saturation, $\mathrm{S}_{\mathrm{e}}$, expresses a normalized water content between the saturated and the residual state of the soil and equals:

$$
\mathrm{S}_{\mathrm{e}}=\frac{\mathrm{S}_{\mathrm{w}}-\mathrm{S}_{\mathrm{r}}}{\mathrm{S}_{\mathrm{s}}-\mathrm{S}_{\mathrm{r}}}
$$

As a result of Equations (2) and (3), the unsaturated permeability, $\mathrm{k}_{\mathrm{w}}$, decreases with the decrease of the soil water content, $\mathrm{S}_{\mathrm{w}}$, and suction increases.

Finally, the soil's strength is defined to complete the unsaturated zone's description. The unsaturated soil's shear strength can be written based on Bishop's effective stress as $[57,58]$ :

$$
\mathrm{s}=\left(\sigma+\mathrm{S}_{\mathrm{e}} \cdot\left|\mathrm{u}_{\mathrm{w}}\right|\right) \cdot \tan \varphi^{\prime}+\mathrm{c}^{\prime} \Leftrightarrow s=\sigma \cdot \tan \varphi^{\prime}+\mathrm{S}_{\mathrm{e}} \cdot\left|\mathrm{u}_{\mathrm{w}}\right| \cdot \tan \varphi^{\prime}+\mathrm{c}^{\prime}
$$

where $\sigma$ denotes the total stress and $\varphi^{\prime}$ and $c^{\prime}$ are the effective soil shear strength parameters. The second term of the expanded form of Equation (4) (which contains the effective saturation degree, the matric suction $\left|\mathrm{u}_{\mathrm{w}}\right|$, and the effective friction angle) represents the effect of suction in the unsaturated soil shear strength.

\subsection{Effect of Rainfall on Slope Stability}

A typical $50 \mathrm{~m}$ deep pit excavation is considered with a mild slope of $14^{\circ}$. This geometry represents a deep excavation for civil infrastructure but not so deep for coal and lignite mines. This height is over the limits of the literature regarding the parametric analysis of artificial (cut or embankment) slopes (see also Section 2). A parametric study was performed for the critical parameters of groundwater depth, soil, and unsaturated zone properties (see Figure 1 and Section 1). The groundwater was considered through a steady-state flow, and the effect of its depth was investigated. The effect of the unsaturated zone was examined through the parameter $g_{a}$, as analyzed in the previous section. Finally, the soil's permeability, the main soil property related to infiltration, was parametrically investigated. The chosen saturated permeability lies in the range of the dominant overburden material of Greek open-pit lignite mines [31].

Figure 7 illustrates the FEM model, including the geometry, the hydraulic characteristics, and the discretized mesh. Two-dimensional (2D) plane strain and drained conditions were used. Vertical boundaries were at a $2 \mathrm{H}$ distance from the slope's crest and toe, respectively. The horizontal bottom boundary was at a distance, $\mathrm{H}$, from the slope's toe to minimize boundary conditions; $\mathrm{H}$ stands for the slope's overall height. A fine mesh was used for FEM, and mesh density was increased in critical areas. The initial hydraulic conditions (before the rain starts) were established by a steady-state flow, defined by two boundary groundwater heads: the water is located at depth $\mathrm{H}_{\mathrm{w}}$ at the left border and the bottom of the excavation.

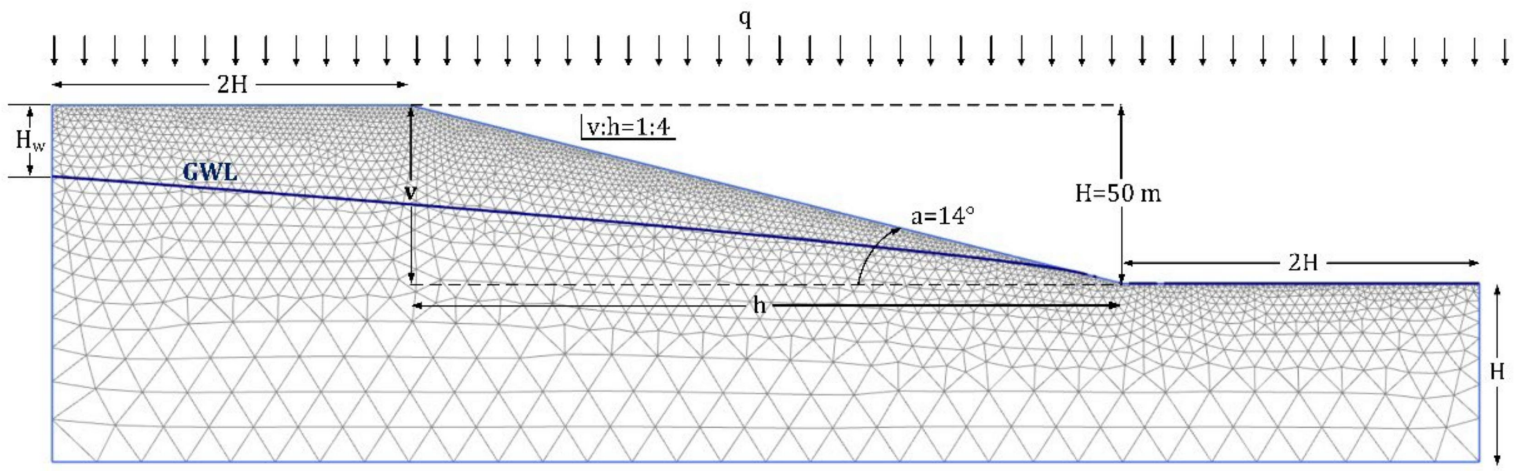

Figure 7. FEM pit slope model's geometry and hydraulic conditions. 
Rainfall intensity was simulated by imposing appropriate boundary flux velocities. Different rainfall intensities were used, representing a wide range. A low-to-medium range from $0.8-6.4 \mathrm{~mm} / \mathrm{h}(19.2-153.6 \mathrm{~mm} /$ day $)$ and two extreme cases, $9 \mathrm{~mm} / \mathrm{h}$ (216 mm/day) and $17 \mathrm{~mm} / \mathrm{h}$ (408 mm/day), are employed based on the climatic measurements and projections analyzed and discussed in the previous sections. The time duration of the rainfall for the simulations is one day $(24 \mathrm{~h})$.

For the reference case, the groundwater head, $\mathrm{H}_{\mathrm{w}}$, was $20 \mathrm{~m}$, and a medium rainfall intensity was chosen of $3.6 \mathrm{~mm} / \mathrm{h}(86.4 \mathrm{~mm} /$ day $)$. All the physical and hydro-mechanical parameters of the reference model's soil material are provided in Table 2 . The fundamental parameters employed in the numerical model, including the geometry (height and angle) and the soil shear strength, have been validated to represent actual cases of Greek lignite mines. The parameters that have not been extensively validated are considered in the parametric analysis that follows to obtain the range of the results. The possible spatial and temporal variability of the basic parameters was not considered in this work to retain the practical and general nature of the framework. Nevertheless, if the soil variability is known, this could be involved in the methodology by applying the appropriate changes in the numerical models.

Table 2. Physical and hydro-mechanical parameters of the simulated soil material.

\begin{tabular}{ccc}
\hline Parameter & Symbol & Value \\
\hline Young's modulus & $\mathrm{E}^{\prime}(\mathrm{MPa})$ & 50 \\
\hline Poisson's ratio & $\gamma^{\prime}(-)$ & 0.25 \\
\hline Effective cohesion & $\mathrm{c}^{\prime}(\mathrm{kPa})$ & 50 \\
\hline Effective friction angle & $\varphi^{\prime}\left(^{\mathrm{o}}\right)$ & 25 \\
\hline Dilation angle & $\psi\left(^{\mathrm{o}}\right)$ & 0 \\
\hline SWCC parameter & $\mathrm{g}_{\mathrm{a}}\left(\mathrm{m}^{-1}\right)$ & 0.01 \\
\hline SWCC parameter & $\mathrm{g}_{\mathrm{n}}(-)$ & 1.3 \\
\hline SWCC parameter & $\mathrm{g}_{\mathrm{l}}(-)$ & 0.5 \\
\hline Bulk water unit weight & $\gamma_{\mathrm{w}}\left(\mathrm{kN} / \mathrm{m}^{3}\right)$ & 9.81 \\
\hline Unsaturated soil unit weight & $\gamma^{\prime}\left(\mathrm{kN} / \mathrm{m}^{3}\right)$ & 16 \\
\hline Saturated soil unit weight & $\gamma_{\mathrm{s}}\left(\mathrm{kN} / \mathrm{m}^{3}\right)$ & 18 \\
\hline Void ratio & $\mathrm{e}_{\mathrm{o}}(-)$ & 0.8181 \\
\hline Residual saturation degree & $\mathrm{S}_{\mathrm{r}}(-)$ & 0.2 \\
\hline Saturated saturation degree & $\mathrm{S}_{\mathrm{s}}(-)$ & 1.0 \\
\hline Saturated permeability & $\mathrm{k}_{\mathrm{s}}(\mathrm{cm} / \mathrm{s})$ & $10^{-4}$ \\
\hline Geostatic stress coefficient & $\mathrm{K}_{\mathrm{o}}(-)$ & 0.3333 \\
\hline
\end{tabular}

The Mohr-Coulomb constitutive model with a non-associated flow rule was used. Four critical parameters were varied to evaluate their effect on stability: the rainfall intensity, the initial groundwater head, $\mathrm{H}_{\mathrm{w}}$, the soil's saturated permeability, and the SWCC parameter, $g_{a}$. Table 3 shows the examined values; all other parameters are kept constant. Typical parameters affecting slope stability, such as the soil's strength, are not investigated. They are well-known to affect slope stability but do not relate to the influence of rainfall infiltration. 
Table 3. Selected values of the investigated parameters.

\begin{tabular}{cccccc}
\hline SWCC material parameter $\mathrm{g}_{\mathrm{a}}\left(\mathrm{m}^{-1}\right)$ & 0.001 & 0.005 & 0.01 & 0.05 & 0.1 \\
\hline Saturated permeability $\mathrm{k}_{\mathrm{s}}(\mathrm{cm} / \mathrm{s})$ & $10^{-5}$ & $5 \times 10^{-5}$ & $10^{-4}$ & $5 \times 10^{-4}$ & $10^{-3}$ \\
\hline Initial groundwater head $\mathrm{H}_{\mathrm{w}}(\mathrm{m})$ & 10 & 15 & 20 & 30 & 40 \\
\hline Rainfall intensity $\mathrm{q}(\mathrm{mm} / \mathrm{h})$ & 1.2 & 2.4 & 3.6 & 4.8 & 6 \\
\hline
\end{tabular}

For the reference case and the $3.6 \mathrm{~mm} / \mathrm{h}$ rain, the average infiltration amount was $28.4 \mathrm{~mm}$ ( $33 \%$ of the rain) and the runoff $58.0 \mathrm{~mm}$ ( $67 \%$ of the rain). Notice that fine-grained soil was simulated, thus a low percentage of rain infiltration was expected. For the very low rainfall of $0.8 \mathrm{~mm} / \mathrm{h}$, this amount rises to $77 \%$, while for the extreme rainfall of $17 \mathrm{~mm} / \mathrm{h}$, this amount becomes $19 \%$. An essential aspect of these amounts is that they are averages and do not entirely reflect the suction conditions and the stability. Although $33 \%$ of the rain infiltrates the slope for the baseline model, near the toe of the slope, all the rain infiltrates, raising the groundwater and crucially altering stability (i.e., the failure surface shape, failure surface place, and the soil's effective stresses and deformations).

The reference case has a very high initial SF, equal to 2.08; the failure surface (Figure 8) is a typical circular surface on homogeneous slopes. This high SF is expected, as the reference model presents a mild slope of medium height for mining excavations. Soil strength is enhanced by the artificial cohesion resulting from matric suction (Figure 9a). At the initial stage, the matric suction - and the related artificial cohesion-increase linearly over the groundwater table, reaching $280 \mathrm{kN} / \mathrm{m}^{2}$ at the slope's crest. As the rainfall infiltrates the slopes, the suction decreases at the slope's edges, where the rainfall infiltrates. Figure $9 \mathrm{~b}$ illustrates the final matric suction distribution in the slope at the end of the one-day rainfall. As time passes, rainfall infiltrates deeper into the soil, and thus a new distribution emerges with zero suction at the slopes' edges and the groundwater table. For fine-grained materials, such as those investigated herein, the suction reduction is the primary mechanism of rainfall affecting slope stability.

Figure 10a displays the effect of the SWCC material parameter, $g_{a}$, on the pit slope's safety factor for a $3.6 \mathrm{~mm} / \mathrm{h}$ intensity rainfall event that lasts $24 \mathrm{~h}$ (total rainfall height equal to $86.4 \mathrm{~mm}$ ). The selected values of the SWCC material parameter, $\mathrm{g}_{\mathrm{a}}$, cover the range of a fine-grained over-consolidated clayey soil. The safety factor reduction rate increases significantly with the decrease of parameter $g_{a}$. In particular, for $g_{a}$ values equal to $0.001 \mathrm{~m}^{-1}, 0.005 \mathrm{~m}^{-1}$, and $0.01 \mathrm{~m}^{-1}$, SF reduces with a rate of $16.5 \%, 10.0 \%$, and $4.7 \%$, respectively. As $g_{a}$ increases further $\left(0.05 \mathrm{~m}^{-1}\right.$ and $\left.0.1 \mathrm{~m}^{-1}\right)$, the slope safety factor is practically constant during rainfall. This difference between the five examined cases is attributed to the shape of the SWCC and the permeability function. Higher $g_{a}$ values correspond to lower suction (lower effective saturation degree) and lower soil permeability values within the unsaturated zone. Thus, as the parameter $g_{a}$ increases, the unsaturated soil permeability, $\mathrm{k}_{\mathrm{w}}$, decreases, and rainwater's infiltration into the unsaturated zone becomes more difficult than before. Indicatively, for the extremes $g_{a}=0.001 \mathrm{~m}^{-1}$ and $\mathrm{g}_{\mathrm{a}}=0.1 \mathrm{~m}^{-1}$, the values of soil's unsaturated permeability, in the area of the slope's crest, are equal to $10^{-5} \mathrm{~cm} / \mathrm{s}$ and $10^{-7} \mathrm{~cm} / \mathrm{s}$, respectively, i.e., they differ by two orders of magnitude. 


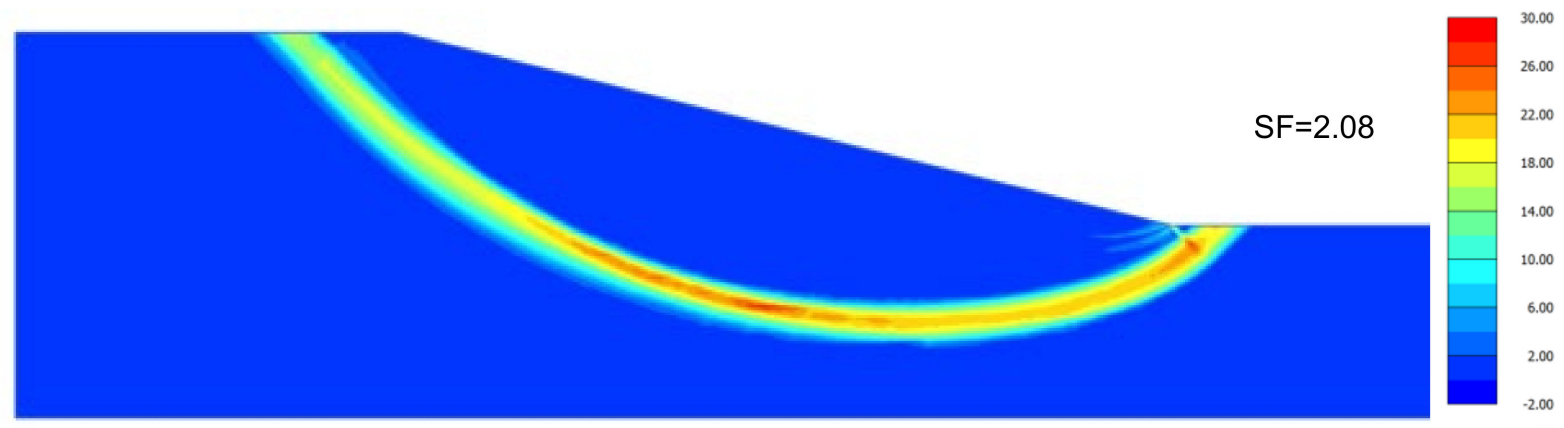

Figure 8. Failure surface characterized by large shear strains for the reference slope.
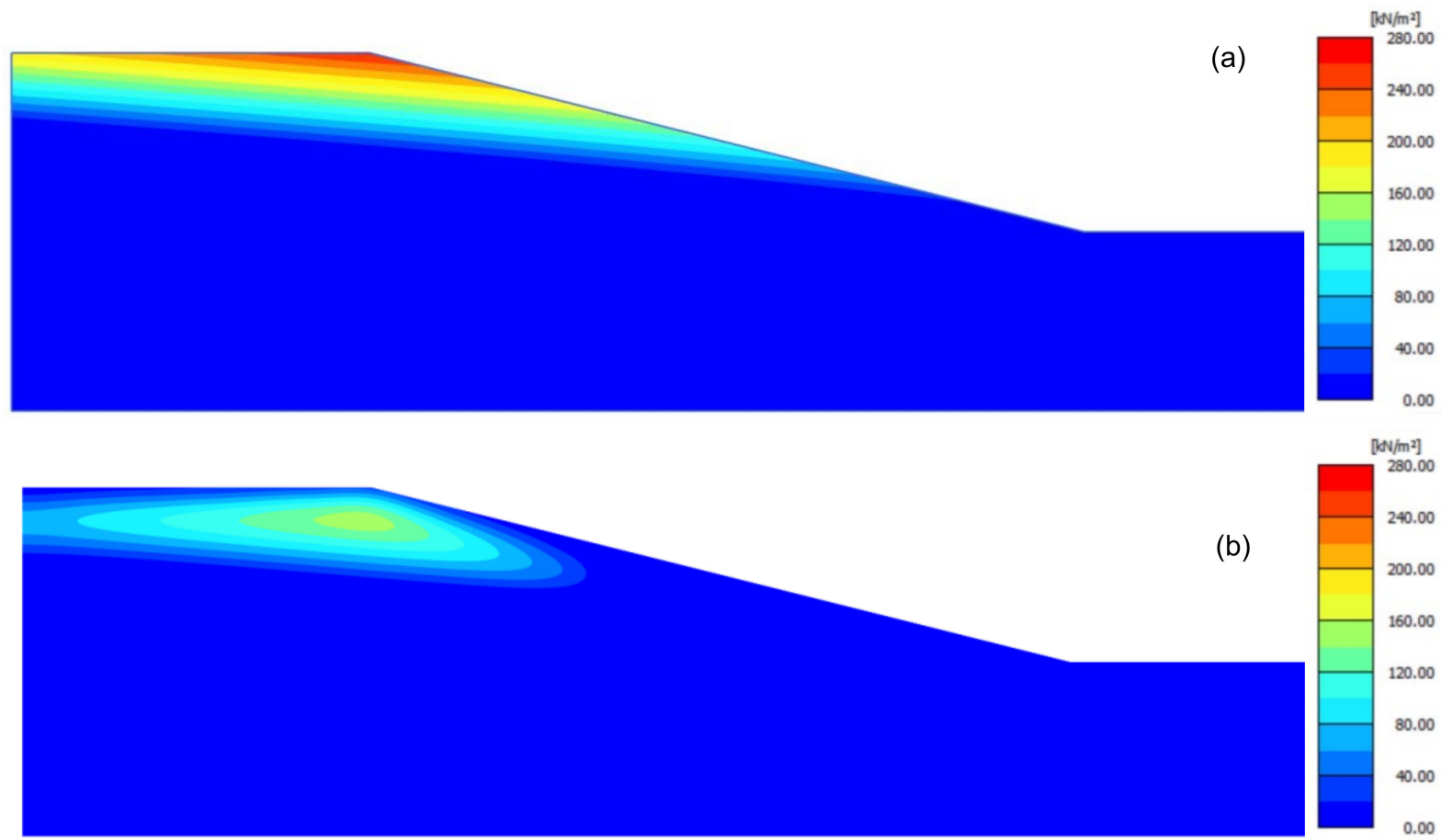

Figure 9. Distribution of matric suction for the reference slope (a) at the initial stage and (b) at the final stage.

Figure $10 \mathrm{~b}$ presents the variation of the pit slope SF for different initial groundwater heads; $\mathrm{H}_{\mathrm{w}}$ ranges from a medium shallow $(10 \mathrm{~m})$ to a deep $(40 \mathrm{~m})$ groundwater table. Before the rainfall, the initial SF increases with the groundwater's head rise-an expected result, since a high groundwater table corresponds to lower SF, whereas a deep groundwater table corresponds to higher SF. During the rainfall event, the safety factor reduction rate decreases with the increase of the groundwater head. The SF's reduction rate for the groundwater head of $\mathrm{H}_{\mathrm{w}}=10 \mathrm{~m}$ is $9.5 \%$, for $\mathrm{H}_{\mathrm{w}}=15 \mathrm{~m}$ is $7.0 \%$, and for $\mathrm{H}_{\mathrm{w}}=20 \mathrm{~m}$ is $4.7 \%$. For the cases of deep groundwater tables corresponding to the high groundwater heads of $\mathrm{H}_{\mathrm{w}}=30 \mathrm{~m}$ and $\mathrm{H}_{\mathrm{w}}=40 \mathrm{~m}$, the slope safety factor is practically constant. Again, high suction stresses and low effective saturation degrees develop in the extended unsaturated zones, leading to lower unsaturated permeability, impeding the infiltration procedure. It is noted that the groundwater head of $\mathrm{H}_{\mathrm{w}}=0 \mathrm{~m}$, corresponding to a groundwater table that starts from the ground surface, was also examined. Since this value corresponds to a high groundwater table, the unsaturated zone's extent is quite limited for large suction stresses to develop. 

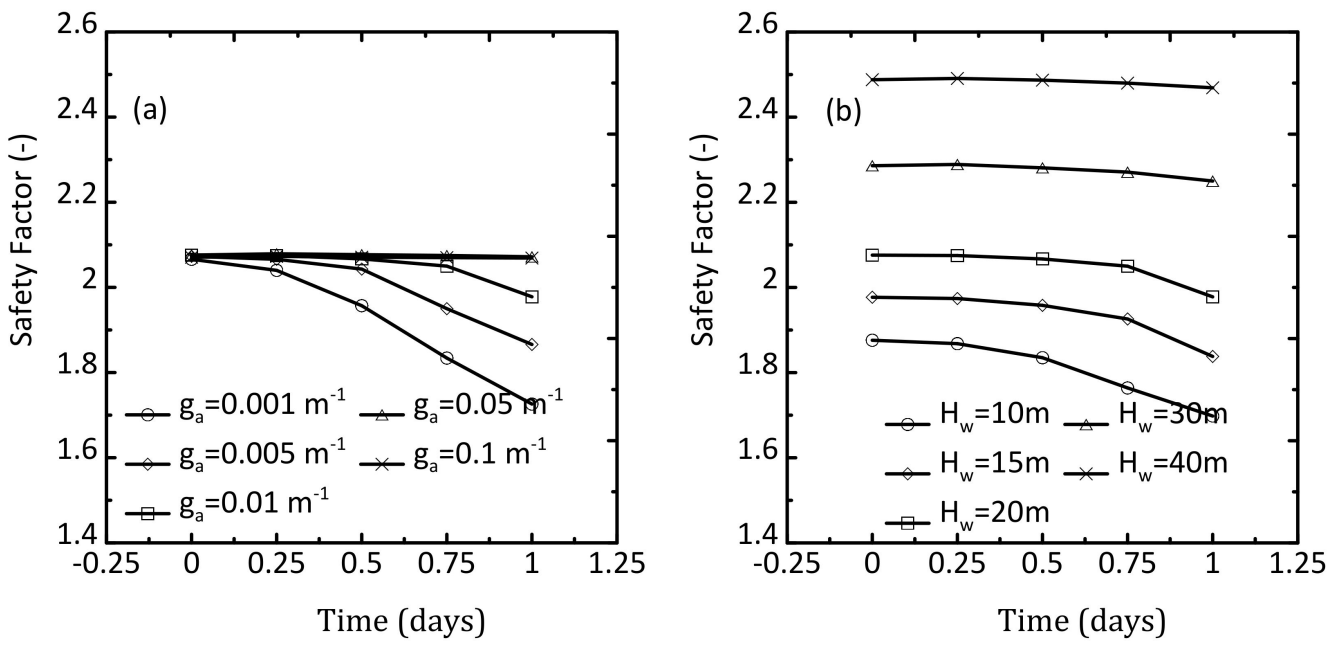

Figure 10. Slope safety factor variation with rainfall time duration, for various values of (a) $g_{a}$ and (b) $\mathrm{H}_{\mathrm{w}}$.

Figure 11a presents the SF with time during rainfall for various values of saturated permeability; the permeability range covers fine-grained but not impermeable soil materials. The reduction rate of the SF during rainfall increases slightly with the increase of the saturated soil permeability. For higher saturated permeability values $\mathrm{k}_{\mathrm{s}}=10^{-3} \mathrm{~cm} / \mathrm{s}$, $5 \times 10^{-4} \mathrm{~cm} / \mathrm{s}$, and $10^{-4} \mathrm{~cm} / \mathrm{s}$, the SF reduction rates are equal to $5.3 \%, 5.1 \%$, and $4.7 \%$, respectively. The slope's SF is practically constant for lower saturated permeability values, $\mathrm{k}_{\mathrm{s}}=5 \times 10^{-5} \mathrm{~cm} / \mathrm{s}$ and $10^{-5} \mathrm{~cm} / \mathrm{s}$. Obviously, as the saturated permeability decreases, soil permeability in the unsaturated zone decreases, and hence water infiltration during rainfall becomes more difficult. The observed minor effect is because of the low values of $k_{s}$.

Figure $11 \mathrm{~b}$ presents SF with time for different rain intensities lasting $24 \mathrm{~h}$. As the rainfall intensity increases, the $\mathrm{SF}$ reduction rate also increases. The $\mathrm{SF}$ is practically constant for the lower rainfall intensity, $0.8 \mathrm{~mm} / \mathrm{h}$ and $2.2 \mathrm{~mm} / \mathrm{h}(19.2 \mathrm{~mm} /$ day and $52.8 \mathrm{~mm} /$ day, respectively). This almost constant $\mathrm{SF}$ is due to the small total rainfall discharge that infiltrates into the relatively large-scale slope of $50 \mathrm{~m}$ height; the total quantity of rainwater is inadequate in inducing a significant dissipation of suction stresses and a decrease of soil's shear strength. As the intensity increases further, it affects the SF more clearly. For the highest value of the medium range- $6.4 \mathrm{~mm} / \mathrm{h}$ or $153.6 \mathrm{~mm} / \mathrm{day}$-and the two extreme intensities $-9 \mathrm{~mm} / \mathrm{h}$ and $17 \mathrm{~mm} / \mathrm{h}$ or $216 \mathrm{~mm} /$ day and $408 \mathrm{~mm} /$ day-the SF decrease is almost the same, and the reduction rates are $8.3 \%, 8.9 \%$, and $9.3 \%$, respectively. Thus, an upper limit is practically identified for the effect of the rainfall intensity on SF, signifying that more extreme rainfall will not further affect the minimum SF reached. 

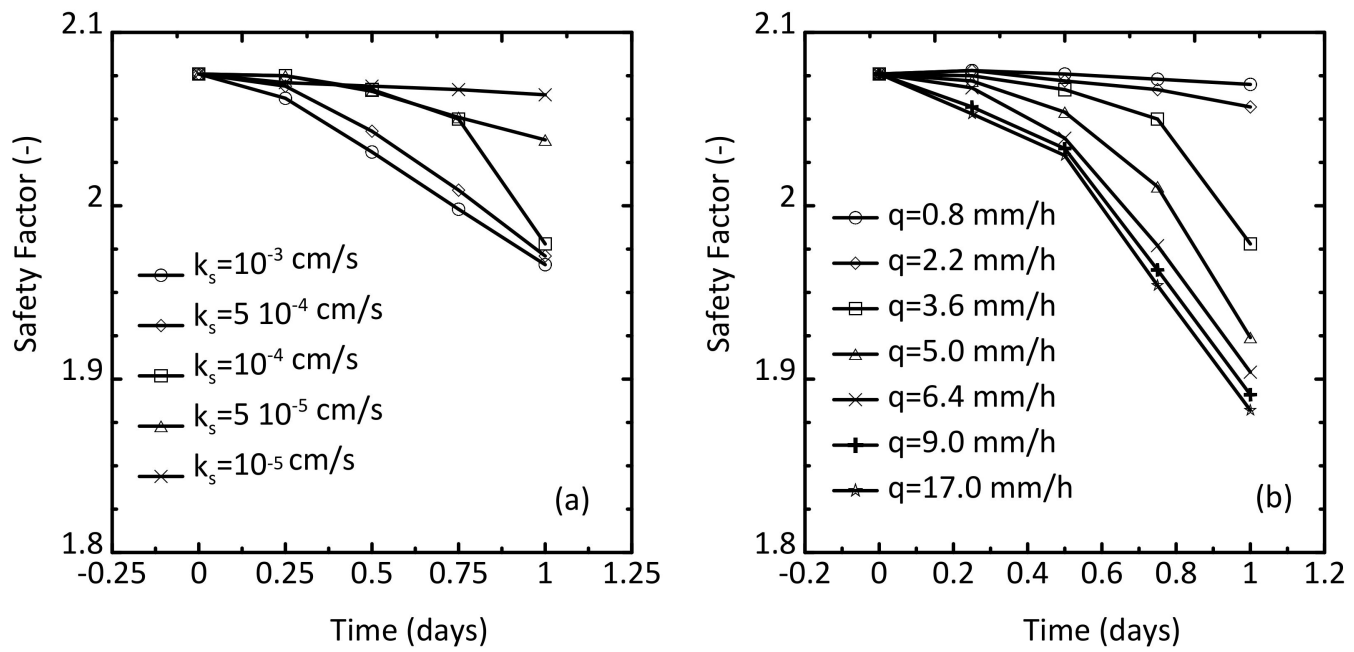

Figure 11. Slope safety factor variation with rainfall time duration, for various values of (a) $k_{s}$ and (b) q.

\section{Discussion}

In this work, a practical framework is proposed (see Figure 1) to assess the effect of rainfall on coal and lignite mines, including details on how to quantify rainfall based on measurements and climate projections. For the case example of Greek lignite mines, it is concluded that slope stability is not jeopardized due to rainfall for the range of the parameters involved. Nevertheless, the changes of the SF due to the four parameters examined above are of general interest. All four parameters are essential for stability and they affect the way rainfall infiltrates the soil. The soil-water characteristic curve affects the unsaturated zone and was investigated in this study through $\mathrm{g}_{\mathrm{a}}$. The considered range of $\mathrm{g}_{\mathrm{a}}$ was rather broad, including the whole range of fine-grained materials, and thus its effect, although important, is not critical. Notice, however, that, in practice, having an accurate estimation of the SWCC is rare, and a broad range should generally be examined. The soil saturation complements the SWCC for the infiltration analysis, which has a similar effect, important but not critical.

Furthermore, the groundwater table's height in the soil slope is critical for stability. That is related to the dewatering operations during a mining excavation and the groundwater conditions before the mine creation. The higher groundwater table suggests greater caution with respect to stability and a more significant impact of rainfall on stability. Finally, the intensity of rainfall is crucial. Of particular interest is medium-to-high rainfall intensity, as this range most affects stability. Very low intensity is inconsequential, while heavy rain practically has the same effect as a medium-to-high intensity. Overall, the results are in accordance with those reported in the previous literature, offering some additional insights into the particular case of slopes of coal and lignite mines.

The current framework could be further advanced in future works incorporating more details in each of its components (climate measurements, climate projections, numerical models) according to the demands of different projects. Climate measurements have been evaluated herein based on average values and trends, and generalizations based on a few registered extreme events. A more advanced statistical analysis could increase accuracy but would require more data and experience. Furthermore, climate models for projections are constantly updated, and thus any advances could be incorporated directly. Finally, spatial and temporal variability in soil properties could be implemented in the seepage and stability analysis. This direction increases accuracy if relevant data are available but complicates the numerical modeling and requires extra caution in the interpretation of results. 


\section{Conclusions}

A new framework has been presented in evaluating coal and lignite mine slope stability due to precipitation. The main advantage of this framework is the comprehensive analysis of climate conditions and rainfall and the numerical slope stability analysis, including all steps in the procedure. Initially, climatic records were documented and analyzed to evaluate the baseline conditions; the focus was mainly on precipitation. Subsequently, the range of rainfall intensity was specified for stability analysis. Rainfall analysis included mean and maximum mean monthly precipitation for the past 30 years and maximum daily rains for the past ten years. This approach was direct and practical; an advanced statistical analysis might have increased accuracy but would have required more detailed data and would have been less practical. The case of Greek lignite mining areas was employed to illustrate the methodology. It was concluded that in the areas under investigation, rainfall intensity varies from very low $(1 \mathrm{~mm} / \mathrm{h})$ to documented intensities up to $9 \mathrm{~mm} / \mathrm{h}$, lasting up to a day $(24 \mathrm{~h})$; very few extreme phenomena in terms of rainfall are documented.

Furthermore, climatic projections of future trends were used to anticipate possible deviations from the baseline rainfall conditions. Nowadays, several methodologies are proposed for climatic projections; some open-access tools have been used and described to evaluate these projections in this work. The tools proposed in this work are readily applicable for most areas, open and free to use, and relatively easily implemented. Rainfall projections show that the reference range of past events is not expected to change significantly in the areas under investigation, independent of future emission scenarios. On the other hand, the mean temperature is expected to increase depending on future emissions.

Finally, the effect of rainfall infiltration on the stability of a typical open-pit lignite mining slope was numerically investigated. The finite element method (FEM) was employed for the groundwater and rainfall analysis and was combined with the shear strength reduction method for stability evaluation. A fully coupled flow-deformation analysis was conducted, allowing for the simultaneous evaluation of the unsaturated transient seepage flow and soil mechanical response.

The impact of the critical factors - the SWCC soil parameter, $g_{a}$, the initial groundwater head, $\mathrm{H}_{\mathrm{W}}$, the saturated permeability, $\mathrm{k}_{\mathrm{s}}$, and the rainfall intensity, $\mathrm{q}$-were investigated through parametric finite element analyses. Rain infiltration primarily produces dissipation of suction stresses in the unsaturated zone, which induces a decrease in unsaturated soil shear strength, with the subsequent deterioration of pit slope stability. However, it is demonstrated that the impact magnitude of the examined parameters varies significantly. According to the numerical results, the effect of the SWCC material parameter, $g_{a}$, in SF's decrease rate during rainfall is more important among the other parameters. As $g_{a}$ decreases, the reduction rate of the pit slope's safety factor during rainfall dramatically increases.

The initial groundwater head, $\mathrm{H}_{\mathrm{w}}$, and the rainfall intensity, $\mathrm{q}$, showed a modest effect in reducing the pit slope's SF. As $\mathrm{H}_{\mathrm{w}}$ decreases (higher initial groundwater table location) or as the rainfall intensity, $\mathrm{q}$, increases, $\mathrm{SF}^{\prime}$ ' reduction rate during rainfall moderately increases. Finally, as the parameter $\mathrm{k}_{\mathrm{s}}$ increases, the $\mathrm{SF}$ reduction rate during rainfall increases slightly. Further work could include a more in-depth sensitivity analysis of the parameters affecting slope stability and various geometries. The particular geometry, stratigraphy, geotechnical, and groundwater conditions should be evaluated for any specific case study.

Author Contributions: Conceptualization, I.E.Z. and N.C.K.; methodology, I.E.Z. and A.I.T.; software, A.V.D. and R.K.; validation, I.E.Z. and A.I.T.; formal analysis, A.I.T.; investigation, A.V.D. and R.K.; resources, I.E.Z. and N.C.K.; data curation, A.V.D. and R.K.; writing-original draft preparation, A.V.D. and A.I.T.; writing-review and editing, I.E.Z., N.C.K. and A.I.T.; visualization, A.I.T.; supervision, I.E.Z. and N.C.K.; project administration, I.E.Z. and N.C.K.; funding acquisition, I.E.Z. and N.C.K. All authors have read and agreed to the published version of the manuscript.

Funding: This work was funded by the European Union's Research Fund for Coal and Steel under the project TEXMIN grant agreement, No. 847250. Financial assistance from the European Commission is greatly appreciated. 


\section{Institutional Review Board Statement: Not applicable.}

Informed Consent Statement: Not applicable.

Data Availability Statement: Not applicable.

Conflicts of Interest: The authors declare no conflict of interest.

\section{References}

1. BP. BP Statistical Review of World Energy; BP p.l.c: London, UK, 2021.

2. Cai, F.; Ugai, K. Numerical Analysis of Rainfall Effects on Slope Stability. Int. J. Geomech. 2004, 4, 69-78. [CrossRef]

3. Chen, X.; Zhang, L.; Zhang, L.; Zhou, Y.; Ye, G.; Guo, N. Modelling rainfall-induced landslides from initiation of instability to post-failure. Comput. Geotech. 2021, 129, 103877. [CrossRef]

4. Robinson, J.D.; Vahedifard, F.; AghaKouchak, A. Rainfall-triggered slope instabilities under a changing climate: Comparative study using historical and projected precipitation extremes. Can. Geotech. J. 2017, 54, 117-127. [CrossRef]

5. Rahardjo, H.; Ong, T.H.; Rezaur, R.B.; Leong, E.C. Factors Controlling Instability of Homogeneous Soil Slopes under Rainfall. J. Geotech. Geoenviron. Eng. 2007, 133, 1532-1543. [CrossRef]

6. Griffiths, D.V.; Lu, N. Unsaturated slope stability analysis with steady infiltration or evaporation using elasto-plastic finite elements. Int. J. Numer. Anal. Methods Geomech. 2005, 29, 249-267. [CrossRef]

7. De Leon, D.; Garduño, J. Time-variant failure probability of critical slopes under strong rainfall hazard including mitigation effects. Struct. Infrastruct. Eng. 2020, 16, 1481-1492. [CrossRef]

8. Mahmood, K.; Ryu, J.H.; Kim, J.M. Effect of anisotropic conductivity on suction and reliability index of unsaturated slope exposed to uniform antecedent rainfall. Landslides 2013, 10, 15-22. [CrossRef]

9. Rahimi, A.; Rahardjo, H.; Leong, E.-C. Effect of hydraulic properties of soil on rainfall-induced slope failure. Eng. Geol. 2010, 114, 135-143. [CrossRef]

10. Chowdhury, R.; Nguyen, V. Risk updating for rainfall-triggered spoil failures. In Proceedings of the International Symposium on Prediction and Performance in Geotechnical Engineering, Calgary, AB, USA, 17-19 June 1987; pp. $439-444$.

11. Pariseau, W.; Schmelter, S.; Sheik, A. Mine slope stability analysis by coupled finite element modelling. Int. J. Rock Mech. Min. Sci. 1997, 34, 242.e1-242.e17. [CrossRef]

12. Steiakakis, E.; Kavouridis, K.; Monopolis, D. Large scale failure of the external waste dump at the "South Field" lignite mine, Northern Greece. Eng. Geol. 2009, 104, 269-279. [CrossRef]

13. Steiakakis, C.; Agioutantis, Z.; Apostolou, E.; Papavgeri, G.; Tripolitsiotis, A. Integrating weather and geotechnical monitoring data for assessing the stability of large scale surface mining operations. Open Geosci. 2016, 8, 694-699. [CrossRef]

14. Lin, H.; Zhong, W. Influence of Rainfall Intensity and Its Pattern on the Stability of Unsaturated Soil Slope. Geotech. Geol. Eng. 2019, 37, 615-623. [CrossRef]

15. Alonso, E.E.; Gens, A.; Delahaye, C.H. Influence of rainfall on the deformation and stability of a slope in overconsolidated clays: A case study. Hydrogeol. J. 2003, 11, 174-192. [CrossRef]

16. Rouainia, M.; Helm, P.; Davies, O.; Glendinning, S. Deterioration of an infrastructure cutting subjected to climate change. Acta Geotech. 2020, 15, 2997-3016. [CrossRef]

17. Ng, C.W.W.; Shi, Q. A numerical investigation of the stability of unsaturated soil slopes subjected to transient seepage. Comput Geotech. 1998, 22, 1-28. [CrossRef]

18. Tsaparas, I.; Rahardjo, H.; Toll, D.G.; Leong, E.C. Controlling parameters for rainfall-induced landslides. Comput. Geotech. 2002, 29, 1-27. [CrossRef]

19. Kim, J.; Jeong, S.; Park, S.; Sharma, J. Influence of rainfall-induced wetting on the stability of slopes in weathered soils. Eng. Geol. 2004, 75, 251-262. [CrossRef]

20. Zhang, L.L.; Fredlund, D.G.; Zhang, L.M.; Tang, W.H. Numerical study of soil conditions under which matric suction can be maintained. Can. Geotech. J. 2004, 41, 569-582. [CrossRef]

21. Rahardjo, H.; Nio, A.S.; Leong, E.C.; Song, N.Y. Effects of Groundwater Table Position and Soil Properties on Stability of Slope during Rainfall. J. Geotech. Geoenviron. Eng. 2010, 136, 1555-1564. [CrossRef]

22. Kim, J.; Jeong, S.; Regueiro, R.A. Instability of partially saturated soil slopes due to alteration of rainfall pattern. Eng. Geol. 2012, 147-148, 28-36. [CrossRef]

23. Hamdhan, I.N.; Schweiger, H.F. Finite Element Method-Based Analysis of an Unsaturated Soil Slope Subjected to Rainfall Infiltration. Int. J. Geomech. 2013, 13, 653-658. [CrossRef]

24. Qi, S.; Vanapalli, S.K. Hydro-mechanical coupling effect on surficial layer stability of unsaturated expansive soil slopes. Comput. Geotech. 2015, 70, 68-82. [CrossRef]

25. Yeh, H.-F.; Tsai, Y.-J. Analyzing the Effect of Soil Hydraulic Conductivity Anisotropy on Slope Stability Using a Coupled Hydromechanical Framework. Water 2018, 10, 905. [CrossRef]

26. Blatz, J.A.; Ferreira, N.J.; Graham, J. Effects of near-surface environmental conditions on instability of an unsaturated soil slope. Can. Geotech. J. 2004, 41, 1111-1126. [CrossRef] 
27. Tommasi, P.; Boldini, D.; Caldarini, G.; Coli, N. Influence of infiltration on the periodic re-activation of slow movements in an overconsolidated clay slope. Can. Geotech. J. 2013, 50, 54-67. [CrossRef]

28. Leshchinsky, B.; Vahedifard, F.; Koo, H.-B.; Kim, S.-H. Yumokjeong Landslide: An investigation of progressive failure of a hillslope using the finite element method. Landslides 2015, 12, 997-1005. [CrossRef]

29. Zhang, J.; Little, D.N.; Hariharan, N.; Kim, Y.-R. Prediction of climate specific vertical movement of pavements with expansive soils based on long-term 2D numerical simulation of rainwater infiltration. Comput. Geotech. 2019, 115, 103172. [CrossRef]

30. Postill, H.; Dixon, N.; Fowmes, G.; El-Hamalawi, A.; Take, W.A. Modelling seasonal ratcheting and progressive failure in clay slopes: A validation. Can. Geotech. J. 2020, 57, 1265-1279. [CrossRef]

31. Theocharis, A.I.; Zevgolis, I.E.; Koukouzas, N.C. A comprehensive geotechnical characterization of overburden material from lignite mine excavations. Geomech. Geophys. Geo-Energy Geo-Resour. 2021, 7, 30. [CrossRef]

32. Kavvadas, M.; Roumpos, C.; Schilizzi, P. Stability of Deep Excavation Slopes in Continuous Surface Lignite Mining Systems. Geotech. Geol. Eng. 2020, 38, 791-812. [CrossRef]

33. Koukouzas, N. Mineralogy and geochemistry of diatomite associated with lignite seams in the Komnina Lignite Basin, Ptolemais, Northern Greece. Int. J. Coal Geol. 2007, 71, 276-286. [CrossRef]

34. Zevgolis, I.E.; Deliveris, A.V.; Koukouzas, N.C. Slope failure incidents and other stability concerns in surface lignite mines in Greece. J. Sustain. Min. 2019, 18, 182-197. [CrossRef]

35. Beck, H.E.; Zimmermann, N.E.; McVicar, T.R.; Vergopolan, N.; Berg, A.; Wood, E.F. Present and future köppen-geiger climate classification maps at 1-km resolution. Sci. Data 2018, 5, 180214. [CrossRef]

36. Eleftheriou, D.; Kiachidis, K.; Kalmintzis, G.; Kalea, A.; Bantasis, C.; Koumadoraki, P.; Spathara, M.E.; Tsolaki, A.; Tzampazidou, M.I.; Gemitzi, A. Determination of annual and seasonal daytime and nighttime trends of MODIS LST over Greece-climate change implications. Sci. Total Environ. 2018, 616-617, 937-947. [CrossRef]

37. Stournaras, G.; Skourtos, M.; Kontogianni, A.; Yoxas, G.; Machleras, A.; Nastos, P. The Environmental, Economic and Social Impacts of Climate Change in Greece; Bank of Greece: Athens, Greece, 2011.

38. Gofa, F.; Mamara, A.; Anadranistakis, M.; Flocas, H. Developing gridded climate data sets of precipitation for Greece based on homogenized time series. Climate 2019, 7, 68. [CrossRef]

39. Feidas, H.; Karagiannidis, A.; Keppas, S.; Vaitis, M.; Kontos, T.; Zanis, P.; Melas, D.; Anadranistakis, E. Modeling and mapping temperature and precipitation climate data in Greece using topographical and geographical parameters. Theor. Appl. Climatol. 2014, 118, 133-146. [CrossRef]

40. Valipour, M.; Bateni, S.M.; Jun, C. Global Surface Temperature: A New Insight. Climate 2021, 9, 81. [CrossRef]

41. Giorgi, F.; Jones, C.; Asrar, G.R. Addressing climate information needs at the regional level: The CORDEX framework. World Meteorol. Organ. (WMO) Bull. 2009, 58, 175.

42. Williams, D.N.; Lawrence, B.N.; Lautenschlager, M.; Middleton, D.; Balaji, V. The earth system grid federation: Delivering globally accessible petascale data for CMIP5. In Proceedings of the 32nd Asia-Pacific Advanced Network Meeting, New Delhi, India, 22-26 August 2011.

43. Henderson-Sellers, A.; McGuffie, K. The Future of the World's Climate; Elsevier: Amsterdam, The Netherlands, 2012.

44. Luhunga, P.; Botai, J.; Kahimba, F. Evaluation of the performance of CORDEX regional climate models in simulating present climate conditions of Tanzania. J. South. Hemisph. Earth Syst. Sci. 2016, 66, 32-54. [CrossRef]

45. Jacob, D.; Teichmann, C.; Sobolowski, S.; Katragkou, E.; Anders, I.; Belda, M.; Benestad, R.; Boberg, F.; Buonomo, E.; Cardoso, R.M.; et al. Regional climate downscaling over Europe: Perspectives from the EURO-CORDEX community. Reg. Environ. Change 2020, 20, 51. [CrossRef]

46. European Environment Agency. Climate Change, Impacts and Vulnerability in Europe 2012: An Indicator-Based Report; $9292133462 ;$ European Environment Agency: Copenhagen, Denmark, 2012.

47. Plaxis 2D Finite Element Geotechnical Analysis Software, version 20.3; Bentley: Dublin, Ireland, 2020.

48. Griffiths, D.V.; Lane, P.A. Slope stability analysis by finite elements. Géotechnique 1999, 49, 387-403. [CrossRef]

49. Fredlund, D.G. The 1999 R.M. Hardy Lecture: The implementation of unsaturated soil mechanics into geotechnical engineering. Can. Geotech. J. 2000, 37, 963-986. [CrossRef]

50. Mualem, Y. A new model for predicting the hydraulic conductivity of unsaturated porous media. Water Resour. Res. 1976, 12, 513-522. [CrossRef]

51. Van Genuchten, M.T. A closed-form equation for predicting the hydraulic conductivity of unsaturated soils. Soil Sci. Soc. Am. J. 1980, 44, 892-898. [CrossRef]

52. Fredlund, M.D.; Fredlund, D.G.; Wilson, G. Prediction of the soil-water characteristic curve from grain-size distribution and volume-mass properties. In Proceedings of the 3rd Brazilian Symposium on Unsaturated Soils, Rio de Janeiro, Brazil, 21-25 April 1997; pp. 13-23.

53. Lazarou, G.; Loukidis, D.; Bardanis, M. Moisture Migration Under Mat Foundations in Nicosia Marl. Geotech. Geol. Eng. 2019, 37, 1585-1608. [CrossRef]

54. Sitarenios, P.; Bardanis, M.; Kavvadas, M. Evaluation of Various Soil-Water Characteristic Curve Models for Soils from Greece. In Unsaturated Soils: Research and Applications; Springer: Berlin/Heidelberg, Germany, 2012; pp. 69-76.

55. Carsel, R.F.; Parrish, R.S. Developing joint probability distributions of soil water retention characteristics. Water Resour. Res. 1988, 24, 755-769. [CrossRef] 
56. Fredlund, D.G.; Xing, A.; Huang, S. Predicting the permeability function for unsaturated soils using the soil-water characteristic curve. Can. Geotech. J. 1994, 31, 533-546. [CrossRef]

57. Bishop, A.W.; Blight, G.E. Some Aspects of Effective Stress in Saturated and Partly Saturated Soils. Géotechnique 1963, 13, 177-197. [CrossRef]

58. Plaxis: Bishop's Effective Stress: Validation \& Verification; Bentley: Dublin, Ireland, 2018. 